\title{
GOOD QUALITIES ARE CORRELATED
}

\author{
Hope for the Eugenist, and One Objection Answered \\ Frederick Adams WoOdS \\ Lecturcr on Biology, Massachusetts Institute of Technology
}

I $T$ is often gratuitously stated that the aims of eugenists will be thwarted because individuals and families possessing rare and desirable qualities are likely, in other important ways, to be decidedly deficient. According to this theory, there is apt to be compensation in the allotment of human gifts. If "some are born fingers, and some are born thumbs," it is assumed that persons over-endowed with thumbs are nevertheless rugged and sturdy and probably staunch in moral fibre. This theory of compensation has been popularized by the emotionally appealing and widely read essay of Ralph Waldo Emerson, which bears the title "Compensation." The philosopher dealt chiefly with the problm of happiness and its dependant spiritual development, and here he may, or may not, be right. However that may be, it is a reasonable assumption that the work of Emerson, as well as that of hosts of other philosophers and preachers, is responsible for the notion that the poor, the sick, the stupid and the generally unfortunate are "the pure in heart," the hallowed possessors of divinely bestowed virtues.

That the exact opposite happens to be the truth, will not interest certain types of emotional and sentimental reformers; but persons desirous of promoting the science of heredity in its application to human problems may be interested in the evidence that accumulates from time to time, all of alhich points in one direction.

There is certainly a slowly growing mass of statistical proof that important mental and moral qualities are correlated. The number of researches is not very extensive, but they should not be overlooked. Most writers on eugenics appear to be unacquainted with the material bearing on this matter and seem thoughtless as to even the existence of such a question. Among authors who have recognized the significance of individual cornelations in eugenic discussions may be mentioned $\mathrm{E}$. L. Thorndike and latterly to some extent Popenoe and Johnson in "Applied Eugenics."

Thorndike in his chapter "Eugenics: With Special Reference to Intellect and Character,"1 accepts the idea of a general correlation of superior and desirable qualities, and quotes Woods" as proving the correlation of intellect with morality, and morality with fecundity, in statistics gathered for measurements of royal families, but does not specifically mention subsequent researches, all of which lead to the view that the correlation of superior qualities is probably a general principle of nature.

Thorndike states the matter as follows :

"If we breed horses for speed, they are likely to lose in strength and vigor. Do we run such risks in breeding men for intellect, or for morals, or for skill? This question has been neglected by the hortatory type of enthusiasts for eugenics. It has not received the attention it deserves from the real workers for racial improvement, probably because the psychological investigations which answer it are little known. They do, however, give a clear and important

1 "Eugenics: Twelve University Lectures." New York, 1914.

2Popular Science Monthly, Oct. 1903, and "Heredity in Royalty." New York, 1906, Mental and moral correlation was found to be $r=.30$. 
answer-that there is practically no chance whatever of injury from selective breeding within a race for intellect, or for morality, or for mental health and balance, or for energy, or for constructive ingenuity and skill - no risk that the improvement of any one of these will cause injury to any of them, or to physical health or happiness."

Among investigations tending to support this theory may be mentioned that of Krueger and Spearman. reported in the Zeitschrift für Psychologie in 1906. The tests made by these authors were five in number, and it should be noted that they were of a nature involving very dissimilar mental faculties. The five tests were as follows:

1. Distinction between pitches of given tones.

2. Combination of fragments of printed texts.

3. Establishment of the limits of the sense of touch.

4. Addition of figures.

5. Ease of committing to memory successive series of numbers.

In spite of the wide difference between having an ear especially sensitive to musical tones, and a brain quick at adding figures, the experimentees, who were brilliant in one of these five directions, were found on the average to be brilliant in the other four.

Recent confirmation of this theory is furnishel by W. H. Pyle in the September, 1918, number of the Journal of Delinquency. He shows, in his article "The Relation of Mental to Physical Development," that there is good evidence that brighter children are also both anatomically and physiologically superior to children of mediocre mentality and that they are physically superior to their duller schoolmates to an even greater degree. ${ }^{3}$

The same issue of the Journal of Delinquency has further evidence bearing on the question of correlations within individuals. WVillis IV. Clark, who is a field-worker in the Whittier State School for Truants, Whittier, California, finds that one-fourth of the white, one-half of the colored, and one-half of the Mexican Indian boys, committed to the school were definitely feebleminded. Only 17.7 per cent of the total number committed were of average-normal or superior intelligence.

Further proof is to be found in the July number of Mental Hygiene (page 445). Here Jessie D. Hodder, Superintendent of the Reformatory for Women, Framingham, Massachusetts, presents statistics which show a slight though measurable correlation between intellectual superiority and freedom from nervous defect. All of the 5,310 cases were women committed to the institution for some form of criminality. The author has classified these individuals into six grades for mentality, (imbecile, moron, subnormal, dull, fair, and good). The method used in classifying is not given, but inasmuch as the material is presented for a purpose other than proving that good qualities are correlated, we may assume that the author has no bias towards such a theory, and we may at least examine the statistics from this standpoint. The percentages of these criminal women who show some form of nervous or mental defect is very high (63.6 per cent) and is itself a manifestation of the joining together of bad qualities. Furthermore, if we sum up the two highest classes in mental grades we find 1,837 persons showing only 39 per cent free from nervous defect, while the three lowest mental classes, 2,390 in number, give an even worse record, or only 34 per cent, free from some one of the four forms of defect here classified under the categories, neuropaths, psychopaths, epileptics and hysterical.

Psychologists have also made tests upon school children and college stup. 286 .

- See also "Body and Mind," in the Joursal of Heredity for June, 1917, Vol. viii, 
dents. The results are summed up in the following quotation," "He who can learn better than the average through the eyes, tends to learn better than the average through the ears; also he who can attend to one thing better than all other men, will be able to attend to many things at once, or in rapid succession, better than most of them. Artistic ability, as in music, painting, or literary creation, goes with scientific ability and matter-of-fact wisdom. The best abstract thinker will be above the average in concrete thought also. The rapid workers are the most accurate. Intellectual ability and moral worth hang together.

The correlations are, of course, not perfect. A large degree of superiority in one desirable trait may involve only a slight superiority in many others. And since the relations vary enormously amongst individuals, a person highly gifted in one respect will often, though not usually, be very inferior in others."

Thus we see that most of the really important characteristics of human beings-such unquestionably desirable attributes, from the common-sense point of view, as health, intellect and morality (here meaning all virtues in their widest sense) are strongly correlated. Special aptitudes are also correlated. More than this, net fertility is correlated with morality and consequently, to some extent, with intellect also. Furthermore, net fertility has been found to be correlated with longevity, which is itself hereditary to a very great extent. ${ }^{\circ}$
All these facts warrant us in assigning an immence importance to the whole principle of corrclations within the individual, and they present a little appreciated though very optimistic outlook for the future of eugenics.

\section{BIBLIOGRAPHY}

Betts, G. H.: “The Distribution of Functions of Mental Imagery," Teachers College, Columbia University Contributions to Education, No. 26, 1909.

Bonser, F. G.: "The Reasoning Ability of Children of the Fourth, Fifth, and Sixth School Grades," do., No. 37, 1910.

Brown, . W.: "Some Experimental Results in the Correlation of Mental Abilities." British Journal of Psychology, vol. 3, pp. 296-322, 1910.

Burt, C.: "Experimental Tests of General Intelligence. British Journal of Psychology, vol. 3, pp. 94-177, 1909.

Spearman, C. : General Intelligence," Objectively Determined. American Journal of Psychology, vol. 5, pp. 201-292, 1904.

Stern, W.: Ueber Psychologie der Individuellen Differenzen, 1900.

Stern, W.: Dic Differentielle Psychologie, 1911.

Whitley, W. T.: "An Empirical Study of Certain Tests for Individual Differences." Archives of Psychology, No. 19. 1911.

Wissler, C.: "The Correlation of Mental and Physical Tests. Psychological Review. Monograph Supplement, No. 16, 1901.

4 Thorndike, Edward L. : "Individuality," Riverside Educational Monographs. Boston: Houghton, Mifflin, 1911 .

s See also B. R. Simpson: "Correlation of Mental Abilities," Teachers' College, Columbia, 1912, p. 122 .

${ }^{\theta}$ Beeton, Miss M., Yule, G. V., and Pearson, K.: "On the Correlation Between Duration of Life and the Number of Offspring," Proc. R. S., London, Vol. LXVII, 1900, pp. 159-171. The material consisted of English and Amorican Quaker families. Also Bell, A. G.: "The Iuration of Life and Conditions Associated with Longevity." Washington, 1918. 57 pp. 